\title{
Brug tussen Doop en Nagmaal
}

JH van Wyk, Hammanskraal

\section{ABSTRACT \\ Bridge between Baptism and the Lord's Supper}

In this article the relation between baptism, confession of faith and holy communion is investigated. It is argued that the relation can only be correctly understood within the context of the covenant and kingdom of God. The confession of faith is concerned with the public acceptance of the promises of God which are sealed in baptism. This must not be understood in a subjectivistic sense as if something in man (his regeneration) is being sealed, or in an objectivistic way as if empty and purely future promises are sealed, but as a real and personal sealing of the promises, as the Heidelberg Catechism says, that God gracefully "grants (present tense!) us remission of sins and the eternal life, for the sake of the one sacrifice of Christ accomplished on the cross" $(25: 66)$. Sacraments are means of God's grace. It is further argued that we must fully accept the personal dimension of the confession of faith: believers confess GOD and not something else. The holy communion is ordained for those who "recognize/discern the body of the Lord", i.e. for those who confessed their faith. In Scripture there is no prescription about the age of confession and participation of the Lord's table. There is much to be said in favour of youngsters partaking of the Lord's table for the strengthening of their faith.

\section{INLEIDING}

Wanneer oor die verhouding doop-belydenis-nagmaal besin word, is dit opvallend dat in die Nuwe Testament - met sy grotendeels sendingsituasie - die volgorde meestal belydenis-doop-nagmaal is. Die belydenis van geloof het nie soseer as brug tussen doop en nagmaal gefunksioneer nie, maar as brug tussen mens en God. In die Nuwe Testament is daar direk na die belydenis gedoop, selfs nog voordat die jong gelowige die betekenis van sy doop ten volle verstaan het (Konig, 1986:192 ev). Duidelik is dat daar ' $n$ baie noue verband tussen doop en belydenis bestaan, ' $n$ band wat in ' $n$ gevestigde kerklike situasie (kinderdoop) gehandhaaf bly, al verander die volgorde van eers doop en daarna belydenis. (Logies hoort die "Formulier by die aflegging van belydenis van geloof" in die Psalmboek tussen die Doopformulier en die Nagmaalsformulier geplaas te word.)

Daar word hier opsetlik van "belydenis" of "geloof sbelydenis" en nie van "aanneming" gepraat nie, soos wat lank die praktyk in selfs die Gereformeerde Kerke in Suid-Afrika was (vergelyk Kruger. 1966 : 367. Bouw- 
man, 1970:368). Die openbare geloofsbelydenis het immers niks met "aanneming" te maak nie. Iemand word met sy belydenis nie "aangeneem" nie, nòg deur die kerk, nòg deur die Here. Aanneming geskied veel eerder deur die doop, en, in Christus, selfs nog daarvoor, "voordat daar tyd of wêreld was" (Skrifberyming 24:1). Want die uitverkiesing is die grondslag, waarborg, hart en kern van die genadeverbond (Bavinck, 1931:256).

Die geloofsbelydenis, het ons gesê, is onlosmaaklik met die doop en nagmaal verbind. In die betrokke Formulier word selfs gesê dat iemand wat belydenis doen, "openlik Gods Verbondsbeloftes aanvaar wat in sy doop verseel is". En in die Kerkorde word in artikel 61 gereël dat "alleen diegene tot die Heilige Nagmaal toegelaat word wat volgens die gebruik van die plaaslike kerk belydenis van die Gereformeerde godsdiens gedoen het en 'n goeie getuienis van 'n vrome wandel besit'. Die verbande tussen doop-belydenis-nagmaal is hiermee aangedui, maar nie teologies uitgespel nie. Hoe moet dit Skriftuurlik gefundeer en teologies uitgebou word? Dit is die vraag wat ons graag tans wil ondersoek. Fundamenteel vir hierdie ondersoek is die wye Skriftuurlike konteks waarbinne hierdie geloofsgoedere funksioneer.

\section{DIE KONTEKS VAN VERBOND EN KONINKRYK}

Die verhouding tussen doop-belydenis-nagmaal kan nooit korrek geformuleer word indien dit nie binne die konteks van die verbond en koninkryk gedoen word nie. Dit blyk nie net uit die Formulier vir die Doop nie maar ook baie duidelik uit die Skrif. Die Formulier praat sommer vroeg daarvan dat die mens as sondaar in die "ryk van God" nie kan kom nie, tensy hy weer gebore word - wat dan deur die doop "geleer" word. En as ons in die Naam van die Vader gedoop word, dan betuig en verseel die Vader aan ons dat Hy 'n ewige "genadeverbond" met ons sluit en dat Hy ons tot sy kinders en erfgename aanneem. Insgelyks handel die Formulier vir die Nagmaal oor die "nuwe testament" en die "ryk van Christus". Doop en nagmaal is tekens en seels van die verbond en die koninkryk.

Ook in die Skrif is hierdie verbande eksplisiet. Die doopbevel in Matteus 28 : 19 staan binne die konteks van die gesagvolle heerskappy (koninkryk!) van Jesus Christus aan wie alle mag in hemel en op aarde gegee is (Floor, 1983:26; Buys, 1985:33 ev). Die doop moet plaasvind in (letterlik tot ) die Naam van die Vader en die Seun en die Heilige Gees, wat beteken dat die dopeling geplaas word onder die verlossende en vernuwende heerskappy van die drie-enige God (Ridderbos in Berkouwer, 1949:533). Wat die nagmaal betref, kan gedink word aan Matteus $26: 26$ - 29 waar die motiewe van verbond en koninkryk ten nouste met mekaar verbind word.

Dit kan ook moeilik anders. Want waar oor die gelowiges, die kerk, die sakramente, die verlossing en vernuwing gehandel word, daar moet noodwendig oor die verbond en koninkryk gehandel word. Inderdaad is die verbond 'n "sleutelbegrip" (Wentsel. 1982:145 ev: 1987:207 ev) en is die verbondsformule die mees voorkomende uitdrukking in die hele Bybel 
(Konig, 1980:71, 73; 1986:271) en loop dit soos 'n goue draad van Genesis 12 oor Jeremia $31: 33$ en Esegiel $37: 27$ tot Openbaring $21: 3,7$.

Die opmerking is gemaak dat die verbond in die Drie Formuliere van Eenheid "geen" (Polman, 1961:462; Heyns, 1978:207) of slegs 'n "terloopse" plek inneem (Wentsel, 1982: 146). Tog moet opgemerk word dat hoewel die woord dikwels ontbreek - nie heeltemal nie - , die saak wel teenwoordig is, soos wat in die briewe van Paulus die woord koninkryk min voorkom. maar die saak oral aanwesig is.

Dit is nie nodig om dit wat in die Skrif spanningloos saam met mekaar funksioneer, naamlik verbond en koninkryk, in die teologie as spanningsvolle konsepte te behandel en byvoorbeeld te vra watter een van die twee die belangrikste is nie. Beide handel immers oor die verhouding tussen God en mens/wëreld. Die verbond beklemtoon die (liefdevolle) gemeenskap tussen God en mens, die koninkryk weer die (genadige) heerskappy van God oor die mens (Wentsel, 1987: 233-235: Konig. 1983:40 ev); die verbond bring gemeenskap, die koninkryk vra gehoorsaamheid. Die verbond is die omvattende en genadige verhouding van gemeenskap waarin God met sy volk wil leef (Ek sal vir julle 'n God wees en julle sal my volk wees) (Konig. 1986: 104-105), terwyl die koninkryk dui op God se handeling met die wêreld (Van Ruler, 1978:33; Wielenga, zj 33). Dit is daarom geensins oordrewe as ook van die koninkryk gesê word dat dit die "sentrale" gegewene van die hele Bybelse verkondiging is (Van Ruler, 1978:32: Ridderbos, 1950:5, 33. 35, 39), dat dit die wesentlike inhoud, kern en doel van die ganse wèreldgeskiedenis is nie (Bavinck, by Van Ruler. 1978:37). In sowel die verbond as die koninkryk gaan dit oor die verhouding tussen God en mens, 'n verhouding wat met die koms van Christus (God met ons) en die Heilige Gees (God in ons), herstel, verinnig en vernuwe is. Dit is ' $n$ verbond en koninkryk van louter genade, want sonder sy toedoen word die mens - ook kinders! - deur die doop in die verbond en koninkryk opgeneem (Floor, 1983:119). So is die kinderdoop die duidelikste teken van die verkiesing van God, wat nie by menslike moontlikhede aanknoop nie (Van 't Spijker, 1980:58). Dit is daarom opvallend dat die sakramente in die Heidelbergse Kategismus juis in die verlossingsleer behandel word (Hartvelt, zj:10) - in die Nederlandse Geloofsbelydenis vorm dit die afsluiting van die ekklesiologie.

Dit is onnodig om hier breedvoerig in te gaan op die vraag wat die Doopformulier bedoel met die "twee kante" van die verbond (die oudste teks lui: "beide delen"). Sommige meen dit dui op die verbondsbeloftes en verbondseise van God (vergelyk Woelderink, 1974:197. 250: Trimp. 1983:171. 184; d'Assonville. 1981:51-52), terwyl ander van oordeel is dat dit in die Bybelse verbondstruktuur altyd oor God en mens gaan (Wielenga. zj: 102-105: Van 't Spijker. 1980:31: Van Campen, 1988:82: Berkhof, 1973:245), al neem God ook eensydig die inisiatief (monopleuriese gehalte en dupleuriese gestalte van die verbond). Hoe die meninge ook al oor die juiste interpretasie van die "twee kante" van die verbond uiteengaan, duidelik is dat die verbond handel oor God en mens, oor verbondsbeloftes en verbondseise. 
Maar wat is hierdie verbondsbeloftes en wat is die verband daartussen en die doop?

\section{DOOP EN BELYDENIS}

Die Heidelbergse Kategismus ( $25: 66$ ) formuleer dat die doop 'n Godgegewe teken en seël is om ons deur die gebruik daarvan "die belofte van die evangelie" des te beter te laat verstaan en te verseël (so Calvyn IV 14:1,3). Die Nederlandse Geloofsbelydenis (artikel 33) sluit hierby aan en voeg by dat die doop 'n waarteken en seël is "van 'n inwendige en onsigbare saak". Die Kerkorde (artikel 56) praat van 'n beseëling "van die verbond van God".

Nou val dit dadelik op dat wanneer die Skrifgegewens hieroor nagegaan word, daar deurgaans persoonliker geformuleer word en wel nie dat iets verseël/beseël word nie maar iemand (vergelyk 2 Kor $1: 22$; Ef $1: 13$, $4: 30$ ). Duidelik is dat in die Skrif die doop in die nouste verband staan met vergewing en verlossing asook met die dood en opstanding van Jesus Christus (Rom $6: 3$ - 4; 1 Kor 1: 13; Ef $5: 25$ - 26; Kol $2: 11$; Heb $6: 4$ ). Die Skrif praat oor die doop asof die heilswerklikheid deur die doop tot stand kom (Hartvelt, zj:38). Dit word onder talle beelde gedoen (Konig. $1986: 10-57)$, wat almal fasette is van die heilswerk van God in ons lewe (Konig, 1986:194). So word na die doop verwys as reiniging van die sonde (Ridderbos, 1966:443 ev, $453 \mathrm{ev}$ ) en as inlywing in (die liggaam van) Christus (Ridderbos, 1966:447 ev: Calvyn IV 15:1).

Ek haal enkele van die belangrikste Skrifuitsprake in hierdie verband aan. In Handelinge $2: 38$ roep Petrus sy toehoorders op tot bekering en doop in die Naam van Jesus Christus "tot vergewing van sondes" (1933-53-vertaling) (vergelyk die Geloofsbelydenis van Nicea waar ons een doop bely "tot vergifnis van sondes"). In Handelinge 22 vertel Paulus van sy bekering en van sy ontmoeting met Ananias en die se woord: "Kom, laat jou doop en jou sondes afwas nadat jy sy Naam aangeroep het" (vers 16) (1983-vertaling). Daar sou verder ook verwys kon word na Rom $6: 4,1$ Kor $6: 11,1$ Kor $12: 13$, Gal $3: 27$, Ef $5: 26$, Kol $2: 12$ en Tit $3: 5$. Frappant is die formulering in 1 Petrus $3: 20-21$ waar die doop met die sondvloed in verband gebring word en gesē word: "Net 'n klein klompie in die ark, ag in getal, is deur die water gered. Dit dui op die doop, waardeur julle ook nou gered word". Om misverstand te voorkom, wys Petrus daarop dat die doop nie 'n afwassing van die vuilheid van die liggaam is nie, "maar 'n bede tot God om 'n skoon gewete, en dit red julle op grond van die opstanding van Jesus Christus" (1983-vertaling). Dit is uit hierdie Skrifgewens voorlopig duidelik dat doop en vergifnis/ redding nie so geidentifiseer kan word dat gesê kan word dat die doop outomaties red nie; andersyds kan doop en vergifnis ook nie so ontkoppel word dat gesē kan word dat slegs die vergifnis/redding belangrik en die doop onbelangrik is nie.

Calvyn maak tereg die opmerking dat Christus die "substansie" van alle sakramente is (IV 14:16). Wanneer Christus uit die oog verloor word, ja meer nog, wanneer die totale konteks waarbinne die doop (en nagmaal) in die Skrif funksioneer, naamlik God, Christus, Gees, Woord en 
geloof, geïgnoreer word, vind daar 'n algehele misduiding van die sakramente plaas (Polman, zj: 150, 159; Berkouwer, 1954:89. 91-92: Konig, 1986:11 ev. 193).

Die Gereformeerde belydenis is duidelik dat net Christus en die Gees, en nie die doopwater nie, ons van alle sonde reinig (HK 27:72). (Selfs Augustinus het aanvaar dat deur die doop swaar sondes vergewe word, 1986:36, 38). Maar beteken dit nou dat die doop 'n verwaarloosde aanhangsel is wat eweseer ontbeer kan word? Waarom verbind die Skrif dit dan met vergewing, vereniging, reiniging en selfs wedergeboorte? Anders gevra: Wat beteken die "verseëling van die belofte van die evangelie"?

In die verband kan drie kante uitbeweeg word. Daar kan eerstens beweer word dat deur die doop iets in die dopeling verseel word (byvoorbeeld sy geloof of - veronderstelde - wedergeboorte); daar kan tweedens gesẽ word dat die doop bloot die (toekomstige) belofte verseel; en daar kán derdens aanvaar word dat die doop God se beloftes aan my verseël.

Die gevaar van subjektivisme (wat 'n variant van Remonstrantisme is) wat in die eerste standpunt na vore kom, lẽ voor die hand en dit is dan ook tereg deur talle teoloë, veral Woelderink (Woelderink. 1974:90 ev; vergelyk Veenhof. 1975: 223: Berkouwer, 1954:204), maar ook deur ander skerp bestry (Bremmer, 1961:295 ev; Lekkerkerker, 1963:123 ev: Holwerda, 1975:376, 392-393: Postma, 1980:19 ev: Floor, 1983:32). Gevolglik verskuif die klem na 'n verseeling van die beloftes van God (vergelyk Venema. zj: 236: Postma. 1980:22; Smit, 1984:13).

Met hierdie klemverskuiwing is die gevaar nie minder groot nie, die gevaar naamlik van objektivisme en 'n blote promiseisme. Wat is immers die waarde van die verseeling van objektiewe en toekomstige beloftes wat nie persoonlik afgestem is nie? En word die realisering van hierdie beloftes nie tog weer op een of ander wyse van die gedoopte afhanklik gemaak, sodat die subjektivisme wat by die voordeur uitgestuur is, tog weer subtiel by die agterdeur ingelaat word nie? Dit gaan tog nie om die verseeling van 'n onpersoonlike belofte wat van 'n persoonlike toeeiening afhanklik gemaak word nie (Berkouwer. 1954:193)?

Die oplossing moet daarin gesoek word dat aanvaar word dat dit in die doop gaan oor 'n verseeling van die belofte van die evangelie vir my. Hierdie persoonlike dimensie mag nie ontbreek nie, omdat die Skrif so leer. Voorts gaan dit ook nie oor beloftes in 'n puur eskatologiese sin nie, asof die beloftes slegs toekomsmusiek is, maar oor beloftes wat in Christus en deur die Gees vervul en gerealiseer is, ten minste in beginsel (Woelderink, 1974:51-52: Veenhof, 1975:224). Die verseëling raak dus nie leë beloftes nie maar gevulde, ja in Christus vervulde beloftes (Bremmer. 1961 : 294: vergelyk Van Campen, 1988:36-40,96-103). Daarom laat die Heidelbergse Kategismus $(25: 66)$ volkome tereg op die verseeling van die belofte van die evangelie volg: "naamlik dat $\mathrm{Hy}$ ons vanweë die enige slagoffer van Christus, wat aan die kruis volbring is, vergewing van sondes en die ewige lewe uit genade skenk" - en nie: sal skenk nie. Die formulering is in die teenwoordige en nie toekomstige tyd nie. Dit 
is dus foutief om te oordeel (soos König, 1986:122) dat die Reformatore die beloftes van God net op die toekoms betrek het.

So is daar in die reformatoriese teologie gewaak teen die uiterste van outomatisme waar die doop ex opere operato die genade instort, soos by Rome (al het Rome nie 'n goedkoop outomatisme geleer nie, vergelyk Berkouwer. 1954:74 ev, en die uiterste van simbolisme waar die doop 'n blote teken is (Zwingli). Die doop is 'n genaderyke gebeurtenis! Daarom hoef daar geen teenstelling te wees wanneer gepraat word van die verseeling van die beloftes en die verseëling van die gelowiges nie (vergelyk Hartvelt, zj:17), omdat dit binne die verbondsrelasie nie oor lee beloftes gaan nie maar oor persoonlik gerigte en gevulde beloftes; die verseeling van die beloftes funksioneer in die verseëling van die gelowiges deur die Heilige Gees (Berkouwer, 1954:203).

Talle gereformeerde teoloë het in afweer teen ' $n$ simbolisme herhaaldelik daarop gewys dat ons in die doop met die heil self te doen het, nie asof die doop die heil bewerk of instort nie, maar as teken en seël daarvan. So skryf Bavinck dat die sakramente nie slegs 'n bevestiging van die "sustensie" van die evangelie is nie, maar vir die gelowiges is dit seels van die ganse genadeverbond, van al sy beloftes, van die ganse Christus en al sy weldade; hulle stort geen fisiese genade in nie, maar skenk die ganse Christus (1930:468; vergelyk Van (ampen, 1988:73-95).

Ook Polman wys in verband met artikel 33 van die Nederlandse Geloofsbelydenis ("waartekens en seels van 'n inwendige en onsigbare saak") daarop dat al hierdie genade (vergewing, wedergeboorte, ensovoorts) deur die sakramente in ons beseel word en wel deur die intermediẻr van die beloftewoord (zj:140). Die tekens (water, brood en wyn) en die betekende saak (Christus), beseeling en bemiddeling, moet dus wel onderskei, maar mag nooit geskei word nie, want God handel nie bedrieglik nie (Polman, zj: 146-147, 157-158: Beker en Hasselaar. 1987: 135, 138). Ridderbos skryf dat die doop en nagmaal die genade voorstel en aan die betrokkenes "deelagtig maak" (in Berkouwer, 1949:529; vergelyk Wielenga, zj:49) .

In die doop gaan dit oor die volle heilsmededeling van God (Konig, 1986: 193, 195). "Solank die doop nie eksklusief en op sigself beskou word nie, maar in sy integrale samehang met die ander heilsmiddele en in sy totale afhanklikheid van die enigste heilsgrond, die heilswerk van Christus, kan ons beswaarlik te veel waarde aan ons doop heg" (Konig. 1986: 197).

Dit gaan in die doop dus nie om 'n outomatiese instorting van genade nie, ook nie oor 'n puur simboliese afbeelding van die genade nie; ook nie oor ' $n$ blote beseeling van die aanbod van die genade nie; ook nie oor ' $n$ beseeling van inwendige genade nie. Dit gaan oor die selfmededeling van die lewende God wat aan die hand van die tekens deur sy Gees heilsaam teenwoordig is. God is inderdaad werksaam.

Indien die gelowige slegs sou konsentreer op wat God gee, kan hy maklik in kwietisme verval; indien hy slegs op die eise sou let, dreig die gevaar van wettisisme; en indien hy slegs met die beloftes sou rekening hou, 
dan is daar die gevaar van promiseisme (vergelyk Polman. 1961:462). In die verbondsleer en doopsleer gaan dit egter om al drie in onlosmaaklike verbondenheid. Dit gaan oor die God wat eis wat Hy belowe en belowe wat Hy eis; die God wat vra wat Hy gee en gee wat Hy vra.

Omdat genade die vertrekpunt is, begin ons altyd by wat God in Christus en deur sy Gees gegee het, naamlik die verlossing en vernuwing, soos wat die wet met sy beloftes en eise by Sinai voorafgegaan is deur die verlossing van Israel uit Egipteland. Die gawe doen egter nie afbreuk aan die belofte nie, soos wat die belofte nie die eis ophef nie.

Dit is teen hierdie agtergrond dat ons 'n sig kry op die belydenisaflegging as openlike aanvaarding van die verseelde verbondsbeloftes van God, 'n tema waaroor daar relatief min besin is (vergelyk Woelderink. 1974:212255: Van 't Spijker. 1980:57-81: Barnard. 1988:58-74: Hovy, 1957). Tereg merk Van 't Spijker op (1980:59, 63) dat die belydenis nie 'n aanvulling van die kinderdoop is nie, maar ' $n$ vervulling van die belofte van die verbond. Die belydenis is geloofsrespons op die doop.

Maar wat moet onder belydenis verstaan word? Wat is die wese daarvan? Is dit 'n belydenis van die kerklike dogma, van die Gereformeerde godsdiens, of van God? Dit is opvallend dat daar vanaf Wezel (1568), toe gepraat is van "belydenis van geloof"', tot Dordt (1618/19), toe gehandel is oor "belydenis van die gereformeerde godsdiens", 'n opvallende verskuiwing in die formulering van artikel 61 van die Kerkorde ingetree het (Bouwman, 1970:368, 374), 'n verskuiwing wat myns betreur moet word, soos weldra sal blyk.

\section{Waarom?}

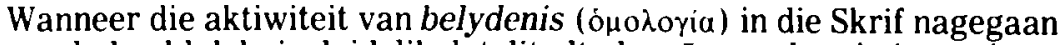
word, dan blyk baie duidelik dat dit altyd op Iemand gerig is en nie op iets nie, op God en Christus en nie op iets anders nie. So lees ons in Matteus $10: 32$ dat Christus praat van iemand wat Hom bely (of verloen) (die konteks is hier natuurlik nie die kerk nie maar die wêreld (Woelderink. 1974:225) ) en in Johannes $9: 22$ gaan dit oor die belydenis dat Jesus die Christus is (vergelyk Matt 16:16). In Romeine $10: 9$ kom dieselfde motief na vore: "As jy met jou mond bely dat Jesus die Here is, en met jou hart glo dat God Hom uit die dood opgewek het, sal jy gered word" (NAV) (vergelyk 1 Kor 12:3). Hierdie persoonlike gerigtheid van die belydenis blyk ook uit Rom $14: 11$ waar daarna verwys word dat elke tong sal bely dat die Here God is (vergelyk Fil $2: 11$ ). En as in 1 Timoteus $6: 12$ (13) van die "goeie belydenis" sprake is, dan gaan dit nie om 'n formele en lee belydenis nie, maar dan gaan dit kennelik om die belydenis van God. En so sou ons kon voortgaan deur te wys op die belydenis van die Naam van Jesus (Heb $13: 15$ ) en op die belydenis van Jesus Christus wat in die vlees gekom het ( 1 Joh $4: 2,3,15$; vergelyk 2 Joh 1:7). Die belydenis waaraan ons moet vashou, staan in die nouste verband met Jesus as Seun van God (Heb $4: 14$; vergelyk $3: 1)$. En selfs wanneer daar sprake is van die "hoop wat ons bely" (NAV) (Heb 10 : 23: vergelyk Rom $8: 24$ ), is dit 'n hoop op die God wat getrou is. selfs al is ons ontrou, omdat Hy Homself nie kan verloen nie. Dit is ook 
opvallend dat daar (na alle waarskynlikheid) in Hebreërs $10: 22$ - 23 'n verband tussen doop (reiniging) en belydenis gelê word.

Uit al hierdie gegewens, wat 'n bevestiging is van die persoonlike en Godgerigte karakter van die Ou Testamentiese geloofsbelydenis (Deut $6: 4$; vergelyk Mark $12: 29$ ), kan net een konklusie getrek word en dit is dat geloofsbelydenis wesentlik op die lewende God gerig is en op niks en niemand anders nie. Dis nie 'n belydenis van 'n kerklike dogma of gereformeerde godsdiens nie, maar van God en van Christus (Woelderink, $1974: 223,227$ ). Die evangelie is geskryf dat mense kan glo dat Jesus die Christus is, die Seun van God, en sodat hulle deur te glo, in sy Naam die lewe kan hê (Joh $20: 31$; vergelyk 2 Tim $3: 15$ ).

Oor hierdie belydenis as 'n persoonlike belydenis van Christus, skryf Bouwman insiggewend en Skriftuurlik (1970:368-374) (en indringender nog as Kruger, 1966:366; vergelyk Van der Linde, 1983:204; Nauta, 1971:269). Dis om hierdie rede dat ek reeds eerder gesê het dat die latere formulering van artikel 61 van die Kerkorde - "belydenis van die Gereformeerde godsdiens" - tot misverstand aanleiding kan gee, omdat "Gereformeerde godsdiens" tog nooit in die plek van God kan staan nie. En dis ook om hierdie rede dat weer ernstig gekyk moet word na die vrae wat vir die belydenisaflegging gebruik word, aangesien die huidige vrae 'n sterk skolastiese inslag het. Dit verdien myns insiens aanbeveling om die belydenis van die drie-enige God eksplisiet voorop ter sprake te bring en dan die vrae daarop te laat volg wat handel oor die aanvaarding van die Ou en Nuwe Testament as betroubare Woord van God en oor die gereformeerde konfessies as in ooreenstemming met die Skrif, asook die belofte van 'n Godvresende lewe.

Die onderskeiding waarvoor ek hier pleit, is dieselfde as wat in die Apostoliese Geloofsbelydenis verwoord is en waarop ook Calvyn attendeer (IV 1:2), naamlik die tussen geloof in God en geloof aan die kerk (ensovoorts). Mens kan nie in iets glo nie, maar slegs in God. Bavinck het op die gevaar gewys dat die aksent verlè kan word van die geloof te bely na die glo van die belydenis. Nie sonder rede nie begin Calvyn sy beroemde Kategismus met die kernvraag oor wat die hoofdoel van die mens se lewe is, en hy antwoord: "Om God te ken". Hieruit mag natuurlik nie die foutiewe afleiding gemaak word dat nie met die Gereformeerde belydenisskrifte volledige instemming betuig sal word en dat dit nie heelhartig aanvaar moet word nie. Dit spreek vanself.

Op hierdie wyse sal die geloofsbelydenis, veral ook indien dit met handoplegging as 'n gebaar van seën kan geskied, soos deur Calvyn bepleit (IV 19:4; vergelyk Van 't Spijker, 1980:62), 'n heerlike gebeurtenis en 'n oomblik van groot vreugde wees. As reformatoriese Christene verskil ons hier van die Rooms-Katolieke Kerk wat die konfirmasie en handoplegging te uitsluitlik met die gawe van die Heilige Gees verbind (Nieuwe Katechismus, 1966:303-304; vergelyk Calvyn IV 19:4-13).

\section{BELYDENIS EN NAGMAAL}

Daar loop ' $n$ bepaalde verbindingslyn van die doop na die nagmaal via 
die geloofsbelydenis. Die Heidelbergse Kategismus (30:81) formuleer dat, algemeen gesproke, slegs gelowiges (wat goed lewe) toegang tot die nagmaal het, terwyl die Kerkorde in artikel 61 praat van diegene wat belydenis van die Gereformeerde godsdiens gedoen het.

Die Skriftuurlike kriterium vir toegang tot die nagmaal is, weer eens algemeen gestel, neergelê in 1 Korintiërs $11: 29$, naamlik dat iemand

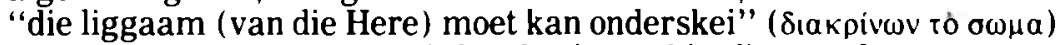
(vergelyk Hartvelt, zj: 102-104). Die betekenis van hierdie woorde moet waarskynlik in die rigting gesoek word dat iemand moet kan onderskei tussen die tafel van die Here en die tafel van die duiwels ( $10: 21)$, maar meer nog: dat iemand moet kan onderskei tussen 'n gewone huismaaltyd en die maaltyd van die Here (Woelderink, 1974: 242; Leon Morris in sy kommentaar op 1 Korintiers $1971: 164)$. Met ander woorde, as iemand nagmaal vier, of

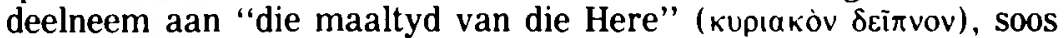
Paulus graag sê $(1$ Kor $11: 20)$, dan moet hy presies weet wat hy doen (Hartvelt, zj:103). Die nagmaal is immers genademiddel, konsentrasiepunt van Gods groot dade in Christus (Trimp, 1983:118), en is selfs, weliswaar oordrewe, beskryf as "die mees omvattende uitdrukking van die heil" (Berkhof, 1973:380), in elk geval "grondslag en kriterium vir die eenheid van die gemeente" (Ridderbos, 1966:473). Die nagmaal is nie minder genademiddel as die Woord nie (Trimp, 1983:118). Beide Woord en nagmaal representeer die heil in sy volheid maar onder verskillende gesigspunte (Berkhof, 1973:381).

Hierdie benadering sluit al dadelik 'n babanagmaal uit maar nie 'n kindernagmaal nie. Die strydvraag is nie of kinders mag nagmaal vier nie, maar of hulle voor belydenis mag nagmaal vier (vergelyk Aalbers, 1971: Muller-Fahrenholz, 1982: Hendriks, 1986). Weliswaar het (selfs baie klein) kinders in die Vroee Kerk nagmaal gevier, en het die Reformasie kinderkommunie oor die algemeen aanvaar (Hartvelt, zj:89, 90), en kom dit vandag nog voor in die Griekse Ortodokse Kerk, en word dit tans deur gereformeerde kerke oorweeg, maar Calvyn het tereg geoordeel dat kinders eers belydenis moet doen voordat hulle mag nagmaal vier (IV $16: 30,31$ : vergelyk Nauta, $1971: 268$ ). Maar dan moet baie duidelik in gedagte gehou word dat kinders in sy tyd op tienjarige ouderdom belydenis gedoen het (IV 19:13). (Bouwman beweer dat Calvyn kinders op veertienjarige ouderdom tot die nagmaal toegelaat het, 1970:384.)

Kinders wat belydenis gedoen het, mag nie van die nagmaal weggehou word nie. nie omdat die belydenis reg van toegang tot die nagmaal verleen (Woelderink. 1974:238) asof dit 'n voorwaarde is op grond waarvan toelating tot die nagmaal verkry word nie: dit is veeleer' $n$ weg waarlangs (Woelderink, 1974:240). Die nagmaal is bedoel vir gelowiges wat kan onderskei. Die sterk aandrang tot 'n ouer en meer selfstandige belydenis is nie noodwendig goed nie: dit weerhou immers kinders die geloofsversterkende krag van die nagmaal tydens 'n krisisperiode van hulle lewe. Tereg wys Bouwman daarop (1970:384) dat die leeftydsgrens van belydenisaflegging gedurende die agtiende en negentiende eeu verhoog is onder invloed van die piëtisme en kwiëtisme wat bekering vooraf geeis het; verder van die kant van die rasionalisme, wat geeis het dat elke 
Christen 'n rasionele bewys van die Christendom moet kan gee; en uiteindelik van die Aufklarung wat verwag het dat elke kind in vryheid uit die verskillende godsdienste moet kan kies. Die nuwe tendens van 'n ouer belydenisaflegging (op agtien jaar) het myns insiens te vlug. voetig oor hierdie swaarwegende argumente van Bouwman heengestap. Calvyn se siening van 'n belydenis op jonger ouderdom opgevolg deur 'n intensiewe na-belydenis-kategese verdien ernstige oorweging. Dit lyk my teologies en psigologies verantwoord om die belydenis op sê twaalfjarige ouderdom af te lê - die ouderdom van Christus se eerste optrede in die tempel (Luk 2) - maar dan opgevolg deur 'n indringende nabelydenis-kategese.

By die onderskeiding kom natuurlik ook die selfbeproewing (1 Kor $11: 28)$. Hiermee bedoel Paulus nie dat gelowiges sal oorweeg of hulle sal nagmaal vier nie, maar hoe hulle sal vier; die selfondersoek is nie gemik op 'n moontlike afhouding van die nagmaal vanweë die baie persoonlike sondes nie, maar bedoel om afstand te doen van die sonde en daarom nagmaal te vier (Hartvelt, zj:66, 107). En heel spesifiek gaan dit hier oor (die korreksie van!) die wanverhouding tot die arm broeder en suster as deelgenote van die maaltyd van die Here (1 Kor 11:3334). Soos Calvyn sê: ons kan geen onenigheid met die broeders hè sonder om ook onenigheid met Christus te hê nie (IV 17:38).

Om die maaltyd van die Here te vier is 'n besondere geleentheid, nee, 'n besondere gebeurtenis. Christus is immers daar heilsaam teenwoordig. Die nagmaal is genademiddel. Dit vestig ons geloofsoog op die gekruisigde, die verhoogde, die teenwoordige en die komende Christus. Dit laat die gelowige terugkyk, boontoe en vorentoe kyk. Dit verbind gelowiges aan Christus en aan mekaar en gryp vooruit na die bruilofsmaal van die Lam (Luk $22: 18$ ). Dit is sowel maaltyd van herinnering (kruis), as maaltyd van gemeenskap (deur die Gees), as maaltyd van belofte (Christus kom).

As genademiddel kan dit alleen tot groot skade nagelaat of onderbeklemtoon word deur dit byvoorbeeld net vier keer per jaar te vier. Uit die Skrif weet ons dat die Vroee Kerk die nagmaal moontlik daagliks gevier het (Hand $2: 46$ ) en later waarskynlik weekliks (Hand 20:7), waarvoor Calvyn ook gepleit het (IV 17:43-46), maar hy moes uiteindelik in 'n maandelikse viering berus (vergelyk Van der Merwe, 1974:23 ("kardinale fout") en 44 ("verkeerd en gevaarlik")). Calvyn sê in sy Kategismus nie om dowe neute dat iemand wat nie nagmaal (wil) vier nie, nie werd is om onder Christene gereken te word nie (antwoord 364).

5. SLOT

Geloofsbelydenis is nie, soos Rome met sy konfirmasie leer, een van sewe sakramente nie. Dit mag egter nie as 'n onbelangrike aangeleentheid weggelaat word nie - by Berkhof, met sy nege "sakramente", ontbreek dit geheel en al (1973:366 ev). Dit is as openbare aanvaarding van Gods verbondsbelofte - Hy sal vir jou 'n God wees en jy sal vir Hom 'n kind wees - 'n geleentheid met 'n besondere karakter. Dit gryp terug na die doop en vooruit na die nagmaal. In al drie, doop, belydenis 
en nagmaal, gaan dit om die God van genade wat ons in Christus en deur sy Gees versoenend tegemoettree en sy hand op ons lé. Selfs al is dit waar dat die gelowige se persoonlike verantwoordelikheid meer by die belydenis en nagmaal as by sy doop beklemtoon word, bly die genade nogtans hoofsaak in al drie. Om gedoop te word, is genade, om belydenis te doen is genade en om nagmaal te vier is genade. Ten diepste kan dit alles teruggevoer word na God se uitverkiesende liefde in Christus, sonder dat die mens se verantwoordelikheid in gedrang kom en die oproep tot bekering geelimineer word

Ons het gesê dat die gelowige met sy belydenisaflegging openlik Gods verbondsbelofte aanvaar sodat hy nou as mondige lidmaat in die kerk as volk van God by alles betrokke kan wees. As belyer van Christus leef hy egter nie net binne die ruimte van die kerk nie maar ook in die wêreld en mag hy hom nooit skaam vir die belydenis van Christus voor die forum van die wêreld nie. Binne en buite die kerk leef hy as koninkrykskind. Hy is ook nie net belydenis-Christen, wat sy belydenis kant en klaar en finaal agter die rug het nie, maar ook belydende Christen, wat elke dag weer in al die kronkelgange van die lewe sy belydenis openlik bevestig en uitleef (Barnard, 1988:58-59). 'n Eenmalige geloofsbelydenis sonder ' $n$ kontinue bevestiging daarvan in die daaglikse lewenspraktyk, is immers waardeloos.

Wie Christus bely, moet Hom altyd en orals bely. Daartoe wil die doop en nagmaal juis ondersteuning bied. Ja, doop en nagmaal is op sigself reeds ' $n$ aktwiteit van belydenis (Woelderink, 1974:237)!

\section{BRONNELYS}

Aalbers, BJ. 1971. Kinderen aan het avondmaal. Kampen: Kok

Aalders, G Ch. 1939. Het verbond Gods: Een hoofdstuk uit de geschiedenis der openbaring. Kampen: Kok

Augustinus, A. 1986. Twintig preken van Aurelius Augustinus. Baarn: Ambo (vert. Gerard Wijdeveld)

Barnard, AC. 1988. Die begeleiding van verbondskinders tot belydenis van geloof In Borchardt. CFA red. Wedergeboorte en bekering in verbondsperspektiel. Pretoria: NG Kerkboekhandel.

Bavinck, H. 1930(4). Gereformeerde Dogmatiek IV. Kampen: Kok 1931 (2) . Magnalia Dei : Onderwijzing in de christelijke religie naar gereformeerde belijdenis. Kampen: Kok.

Beker, EJ \& Hasselaar. JM. 1987. Wegen en kruispunten in de dogmatiek 4: Over de Heilige Geest en de sacramenten. Kampen: Kok.

Berkhof, H. 1973 Christelijk Geloof : Een inleiding tot de geloofsleer. Nijkerk Callenbach

Berkouwer, GC. 1954. De sacramenten. Kampen: Kok \& Toornvliet. G. 1949. Het dogma der kerk. Groningen: Haan.

Bouwman, H. 1970(2) . Gereformeerde Kerkrecht II : Het recht der kerken in de practijk. Kampen: Kok

Buys, PJ. 1984. Die aard van die verbond en die implikasies daarvan vir evangelisasie. Vereeniging (ongepubl)

Bremmer. RH. 1961. Herman Bavinck als dogmatikus. Kampen: Kok.

Calvijn. J zj. 3e dr. Institutie of Onderwijzing in de Christelijke Godsdienst III. Delft : Meinema (vert. A Sizoo).

Calvyn se Kategismus. 1981. Potchefstroom: PTP (vert. HW Simpson).

d'Assonville, VE. 1981. Die Gereformeerde Doopsformulier. Potchefstroom: Marnix

De Klerk, PJS. 1943. Kerk en Verbond. Stellenbosch: Pro Ecclesia 
Durand, JJF. 1982. Skepping, mens, voorsiënigheid: W̌egwysers in die dogmatiek. Pretoria: NG Kerkboekhandel.

Floor, L. 1983. Die Heilige Doop in die Nuwe Testament. Potchefstroom: PTP.

Hartvelt, GP zj. Tastbaar evangelie: Nieuwe Commentaar Heidelbergse Catechismus III. Aalten: De Graafschap.

Hendriks, AN. 1986. Kinderen aan de tafel van Christus? Kampen: Van den Berg. Heyns, JA. 1978. Dogmatiek. Pretoria: NG Kerkboekhandel.

Holwerda, B. 1975(2). De dingen die ons van God geschonken zijn: Catechismus-predicatien. Goes: Oosterbaan \& Le Cointre.

Hovy, W red. 1957. Die lewende lidmaat. Potchefstroom: Pro Rege.

Konig, A. 1980. Jesus die Laaste. Gelowig nagedink Deel 2: Oor die einde. Pretoria: NG Kerkboekhandel.

1983. Heil en heilsweg. Pretoria: NG Kerkboekhandel

1986. Die doop as kinderdoop en grootdoop. Pretoria: NG Kerkboekhandel.

Kruger, LS ea. 1966. Handleiding by die Kerkorde van die Gereformeerde Kerk in Suid-Afrika. Potchefstroom: Pro Rege Pers.

Lekkerkerker, AFN. 1963. Gij zijt gedoopt. Baarn: Bosch \& Keunig 1964. Gesprekken over de Heidelberger. Wageningen: Zomer \& Keunings.

Muller-Fahrenholz, G red. 1982. And do not hinder them: An ecumenical plea for the admission of children to the eucharist. Geneve: WCC.

Nauta, D. 1971. Verklaring van de Kerkorde van de Gereformeerde Kerken in Nederland. Kampen: Kok.

Nieuwe Katechismus, De: Geloofsverkondiging voor volwassenen. 1966. Hilversum: Brand. (In opdracht van de bisschoppen van Nederland.)

Polman, ADR zj. Onze Nederlandsche Geloofsbelijdenis: Verklaard uit het verleden, geconfronteerd met het heden IV. Franeker: Wever. 1961(2). Verbond (In Christelijke Encyclopedie VI. Kampen: Kok, 460-462.)

Postma, D. 1980. Prediking en Verbond. Potchefstroom: CJBF.

Reumann, J. 1985. The Supper of the Lord: The New Testament, ecumenical dialogues, and Faith and Order on eucharist. Philadelphia: Fortress Press.

Ridderbos, HN. 1950. De komst van het koninkrijk : Jezus' prediking volgens de synoptische evangelien. Kampen: Kok.

Ridderbos, H. 1966. Paulus: Ontwerp van zijn theologie. Kampen: Kok.

Smit, CJ. 1984. Die belang van die doop vir u kind: Wat sê die Heilige Skrif? Pretoria: NG Kerkboekhandel.

Trimp, C. 1983. De gemeente en haar liturgie: Een leesboek voor kerkgangers. Kampen: Van den Berg.

Thurian, M \& Wainwright. G red. 1983. Baptism and Eucharist: Ecumenical convergence in celebration. Grand Rapids: Eerdmans.

Van Campen, M. 1988. Leven uit Gods beloften: Een centraal thema bij Johannes Calvijn. Kampen: Goudriaan.

Van der Linde, GPL. 1983. Die Kerkorde: 'n Verklaring van die Gereformeerde Kerkorde. Potchefstroom: PTP.

Van der Merwe, DCS. 1974. Elke Sondag nagmaal? Gewetenssaak vir elke Christen. Potchefstroom: Pro Rege.

Van Ruler, AA. 1978. Verwachting en voltooiing: Een bundel theologische opstellen en voordrachten. Nijkerk: Callenbach.

Van 't Spijker, W. 1980. Zijn verbond en woorden: Over doop, belijdenis en avondmaal volgens de klassieke formulieren. Goudriaan: De Groot.

1986. Gereformeerden en Dopers: Gesprek onderweg. Kampen: Kok.

Veenhof, J. Des 1975 . De theologie van J. G. Woelderink. Gereformeerd Theologisch Tijdschrift, $75: 220-228$.

Venema. FF zj $5 \mathrm{e} \mathrm{dr}$. Wat is een Christen nodig te geloven? Groningen: De Vuurbaak.

Wentsel, B. 1982. De openbaring, het verbond en de apriori's. Dogmatiek deel 2. Kampen: Kok.

1987. God en mens verzoend: Godsleer, mensleer en zondeleer. Dogmatiek deel 3a. Kampen: Kok.

Wielenga, B. zj. 2e dr. Ons doopsformulier. Kampen: Kok.

Woelderink, JG. 1974. Verbond en bevinding. Amsterdam: Bolland. 